Marquette University

e-Publications@Marquette

Theology Faculty Research and Publications

Theology, Department of

$1-1-2004$

Noah's Younger Brother Revisited: Anti-Noachic Polemics and the Date of 2 (Slavonic) Enoch

Andrei Orlov

Marquette University, andrei.orlov@marquette.edu

Published version. Henoch, Vol. 26, (2004): 172-87. Publisher link. (C) 2004 Morcelliana. Used with permission. 
HENOCH, VOL. XXVI, 2004

\title{
NOAH'S YOUNGER BROTHER REVISITED: ANTI-NOACHIC POLEMICS AND THE DATE OF 2 (SLAVONIC) ENOCH
}

\author{
Andrei A. Orlov, Marquette University, Milwaukee
}

Several years ago, in an article published in this journal, I argued that 2 Enoch contains systematic polemics against the priestly Noachic tradition. ${ }^{1}$ My study tried to demonstrate that in the course of these polemics the exalted features of Noah's story, such as his miraculous birth, his leading roles as the originator of animal sacrificial practice and a bridge over the Flood become transferred to other characters of the Slavonic apocalypse including Methuselah, Nir, who is defined in the story as "Noah's younger brother," and his miraculously born child Melchisedek. ${ }^{2}$ The analysis showed that the transferences of Noah's features and achic-

${ }^{1}$ A. Orlov, "Noah's Younger Brother': Anti-Noachic Polemics in 2 Enoch," Henoch 22.2 (2000) $259-73$.

${ }^{2}$ Noachic polcmics take place in the last chapters of the Slavonic apocalypse (chs 68-72). In this section of the pseudepigraphon we learn that, immediately after Enoch's instructions to his sons during his short visit to the earth and his ascension to the highest heaven, the firstborn son of Enoch, Methuselah, and his brothers, the sons of Enoch, constructed an altar at Achuzan, the place where Enoch had been taken up. In 2 Enoch 69 the Lord appeared to Methuselah in a night vision and appointed him the priest before the people. Verses $11-16$ of this chapter describe the first animal sacrifice of Methuselah on the altar. The text gives an elaborate description of the sacrificial ritual during which Methuselah slaughters with a knife, "in the required manner," sheep and oxen placed at the head of the altar. All these sheep and oxen are tied according to the sectarian instructions given by Enoch earlier in the book. Chapter 70 of 2 Enoch recounts the last days of Methuselah on earth before his death. The Lord appeared to Methuselah in a night vision and commanded him to pass his priesthood duties on to the second son of Lamech, the previously unknown Nir. The text does not explain why the Lord wanted to pass the priesthood to Nir instead of Noah (Lamech's firstborn son), cven though Noah is also mentioned in the dream. Further, the book tells that Methuselah invested Nir with the vestments of priesthood before the face of all the people and "made him stand at the head of the altar." 'The account of the sacerdotal practices of Enoch's relatives then continues with the Melchisedek story. 'The content of the story is connected with Nir's family. Sothonim, Nir's wife, gave birth to a child "in her old age," right "on the day of her dearh." She conceived the child, "being sterile" and "without having slepc with her husband." The book told that Nir the priest had not slept with her from the day that the Lord had appointed him in front of the face of the pcople. Therefore, Sothonim hid herself during all the days of her pregnancy. Finally, when she was at the day of birth, Nir remembered his wife and called her to himself in the temple. She came to him and he saw that she was pregnant. Nir, filled with shamc, wanted to cast het from him, but she dicd at his feet. Melchisedek was born from Sothonim's corpse. When Nir and Noah came in to bury Sothonim, they saw the child sitting beside the corpse with "his clothing on him." According to the story, they were 
vements to other characters were intended to diminish the extraordinary role traditionally assigned to the hero of the Flood in the crucial juncture of the primeval history.

While demonstrating the existence of the Noahic polemics my previous study did not fully explained the purpose of these polemics. Why Noah who tradirionally is viewed as the main ally of the seven antedeluvian hero in early Enochic booklets suddenly become devalued by the Enochic tradition? In this current investigation I will try to advance an argument that the polemics with the exalted figure of the hero of the Flood found in 2 Enoch might represent the response of the Enochic tradition to the challenges posed to the classic profile of the seventh antediluvian hero by the Second Temple mediatorial traditions about the exalted patriarchs and prophets.

A further, and more important, goal of this study will be clarification of the possible date of 2 Enoch which represent a crucial problem for the students of the Slavonic apocalypse who often lament the absence of a single unambiguous textual evidence that can place the pseudepigraphon in the chronological boundaries of the Second Temple Judaism. Scholars have rightly observed that "although many commentators take for granted a date as early as the first century CE for 2 Enoch, the fact remains that it survives only in Medieval manuscripts in Slavonic and that exegesis of it needs to commence at that point and proceed backwards to a putative (and ... highly debatable) first-century Jewish original only on the basis of rigorous argument." ${ }^{3}$

It is possible that the anti-Noachic developments found in the Slavonic apocalypse can finally provide the decisive proof for the early date of this text. The investigation will explore whether Noachic polemical developments, which focus the issues of sacrificial practices and priestly successions, can be firmly dated not later than $70 \mathrm{CE}$ since they reflect a distinctive sacerdotal situation peculiar to the time when the Temple was still standing. This study will try to demonstrate that the Noachic polemics in 2 Enoch belong to the same stream of early Enochic testimonies to the priestly-Noah tradition as those reflected in the Genesis Apocryphon and the Epistle of Enoch, written before the destruction of the Second Jerusalem Temple.

terrified because the child was fully developed physically. The child spoke with his lips and he blessed the Lord. According to the story, the newborn child was marked with the sacerdotal sign, the glorious "badge of priesthood" on his chest. Nir and Noah dressed the child in the garments of priesthood and they fed him the holy bread. They decided to hide him, fearing that the people would have him put to death. Finally, the Lord commanded His archangel Gabriel to take the child and place him in "the paradise Eden" so that he might become the high priest after the Flood. 'Ihe final passages of the story describe the ascent of Melchisedek on the wings of Gabriel to the paradise Eden.

${ }^{3}$ J. Davila, "Melchisedek, the 'Youth,' and Jesus," in: The Dead Sea Scrolls as Background to Postbiblical Judaism and Early Christianity. Papers from an International Conference at St. Andrews in 2001 (ed. J. R. Davila; STDJ, 46; Leiden; Brill, 2003) 261, n. 20. 


\section{Purpose of the Polemics}

My study published in Henoch $b^{4}$ demonstrated that 2 Enoch shows a systematic tendency to diminish or refocus the priestly significance of the figure of Noah. These revisions take place in the midst of the debates about sacrificial practice and priestly succession. But what is the role of this denigration of the hero of the Flood and the traditions associated with his name in the larger framework of the mediatorial polemical interactions found in the Slavonic apocalypse?

I have argued elsewhere that the anti-Noachic developments are not the only polemical trend found in the Slavonic apocalypsc. ${ }^{5}$ In fact 2 Enoch reveals an intricate web of the mediatorial debates in course of which the several traditions about exalted patriarchs and prophets prominent in the Second Temple Judaism, including Adam and Moses, underwent polemical appropriation when their exaltcd features arc transferred to the seventh antediluvian hero. These polemical tendencies seem to reflect the familiar atmosphere of the mediatorial debates widespread in the Second Temple period which offered contending accounts for the primacy and supremacy of their exalted heroes. The polemics found in 2 Enoch is part of these debates and represent a responsc of the Enochic tradition to the challenges of its rivals.

It has been mentioned that 2 Enoch contains polemics with Adamic and Mosaic traditions. These polemical moves are consistent with the ambiguous attitude towards Adam and Moses already discernable in the earliest Enochic materials where these two exalted characters are traditionally understood as the major mediatorial rivals of the seventh antediluvian patriarch. ${ }^{6}$ But why do the authors of the Slavonic apocalypse attempt to diminish the significance of Noah, who was traditionally considered as a main ally of the seventh antediluvian patriarch and, consequently, occupied a prominent place among the main heroes of the Enochic lore starting from the earliest Enochic booklets?

The important feature of the removal of Noah's priestly and sacrificial roles in 2 Enoch is that, although the significance of the hero of the flood is almost completely sacerdotally denigrated, it does not affect or destroy the valuc or mcaning of the alternative priestly tradition which he was faithfully representing for

${ }^{4}$ A. Orlov, "'Noah's Younger Brother': Anti-Noachic Polemics in 2 Enoch," Henoch 22.2 (2000) 259-73.

5 A. Orlov, "On the Polemical Nature of 2 (Slavonic) Enoch: A Reply to C. Böttrich," Journal for the Study of Judaism 34 (2003) 274-303; Idem, "Without Measure and Without Analogy:' Sh'iur Qomah 'I raditions in 2 (Slavonic) Enoch," Journal of Jewish Studies (2005) (forthcoming).

"See: J. VanderKam, "The Interptetation of Genesis in 1 Enoch," in: The Bible at Qumran (eds. P. W. Flinc and T. H. Kim; Grand Rapids: Eerdmans, 2000) 142; P. Alexander, "From Son of Adam to a Second God: "Transformation of the Biblical Enoch," Biblical Figures Outside the Bible (ed. M.E. Stone and T.A. Betgen; Harrisburg: Trinity Press International, 1998) 100; Idem, "Fnoch and the Beginnings of Jcwish Intercst in Natural Science," in: The Wisdom Texts from Qumran and the Development of Sapiental Thought (eds. C. Hempel et al., BETI., CLIX; Leuven: Pcetcrs, 2002) 234; Orlov, "On the Polemical Nature of 2 (Slavonic) Enoch: A Reply to C. Böttrich," 276-7. 
such a long time. The legacy of this pricstly-sacrificial office is still strictly maintained within the Enochic family since Noah's priestly garments are not lost or destroyed but instead are skillfully transferred to other kinsmen of the Enochic clan, including its traditional member Methuselah ${ }^{7}$ and two other, newly-acquired relatives, $\mathrm{Nir}^{8}$ and Melchisedek. ${ }^{9}$

This shows that the impetus for the denigration of Noah, this important character of the Enochic-Noachic axis, does not come from opponents to the Enochic tradition, but rather originates within this lore. It represents a domestic conflict that attempts to downgrade and devalue the former paladin who has become so notable that his exalted status in the context of mediatorial interactions now poses an imminent threat to the main hero of the Enochic tradition. It is noteworthy that in the course of the aforementioned polemical transferences, the priestly profile of Enoch and the sacerdotal status of some members of his immediate family become much stronger. His son Methuselah, the first-born and heir of his father's teaching, has now acquired the roles of high priest and pioneer of animal sacrificial practice by constructing an altar on the high place associated with the Jerusalem Temple. ${ }^{10}$ Further, it should not be forgotten that the pricst Nir is also a member of Enoch's family, so the future priest Melchisedek, who despite the fact of his bizarre fatherless birth, is nevertheless safely brought into the circle of Enoch's family through his adoption by Nir. ${ }^{11}$ The priestly succession from Enoch and Methuselah to Shem-Melchisedek, an important carrier of sacrificial precepts, thus occurs without the help of Noah. Moreover this enigmatic heir of Enoch's priestly tradition is then able to survive the Deluge not in the ark of the hero of the Flood, but through translation, like Enoch, to heaven.

Enoch also seems to have benefited from Noah's removal from priestly and sacrificial duties since this has made him the only remaining authority in sacrificial instruction, an office that he shared previously with Noah. ${ }^{12}$ 'I his fact might have encouraged him to openly deliver a series of sacrificial halakhot to his children that he never did previously in the Enochic materials. ${ }^{13}$

It is also significant that, although the priestly profile of Noah is removed in the text and his elevated qualities are transferred to other characters, he still remains a faithful member of the Enochic clan. Although he ceases to be an extraordinary

7 Orlov, "Noah's Younger Brother': Anti-Noachic Polemics in 2 Enoch," 209.

8 Orlov, "'Noah's Younger Brother': Anti-Noachic Polemics in 2 Enoch," 210.

9Orlov, "Noah's Younger Brother': Anti-Noachic Polemics in 2 Enoch," $216 \mathrm{ff}$.

102 Enoch 68-69. F. Andersen, "2 (Slavonic Apocalypse of) Enoch," The Old Testament Pseudepigrapha (ed. J.H. Charlesworth; New York: Doubleday, 1985 [1983]) 1.196-199.

11 In 2 Enoch 71 Nir says to the Lord: "For l have no descendants, so ler this child take the place of thy descendants and become as my own son, and you will counc him in the number of your servants." Andersen, "2 (Slavonic Apocalypse of) Enoch," 209.

12 Orlov, "Noah's Younger Brother': Anti-Noachic Polemics in 2 Enoch," 210-12.

132 Enoch 59. Andersen, "2 (Slavonic Apocalypse of) Enoch," 184-87. 
figure and peacefully surrenders his prominent offices to his relatives, he still manages to perfectly fit in the family surroundings by virtue of his newly-acquired role of an average person and a family helper in the new plot offered by 2 Enoch's authors. ${ }^{14}$ This depiction of Noah as an ordinary person provides an important key for understanding the main objective of Noachic polemics in the Slavonic apocalypse as an argument against the exalted profile of the hero of the Flood posing as a mediatorial rival of Enoch.

The changing attitude toward Noah as a potential threat to Enoch's exalted role might already be detected in the late Second Temple Enochic developments. A tradition preserved in the Ethiopic text of the Animal Apocalypse ${ }^{15}$ portrays Noah with imagery identical to that used in the portrayal of Moses in the Aramaic and Ethiopic versions of the text, that is, as an animal transformed into a human; in the zoomorphic code of the book this metamorphosis signifies the transformation into an angelomorphic creature. The Aramaic fragments of 1 Enoch do not attest to the tradition of Noah's elevation, which suggests that this tradition was a later Second Temple development. ${ }^{16}$ It might indicate that in the later Second Temple Enochic lore, about the time when 2 Enoch was written, Noah was understood as an angelomorphic creature similar to Moses, thus posing a potential threat to the clevated profile of the seventh antediluvian hero.

\section{Debates about the Date}

The foregoing analysis of Noachic polemics in the Slavonic apocalypse points to the complex process of interaction between the various mediatorial streams competing for the primacy of their heroes. Yet these conceptual engagements allow us not only to gain a clearer view of the enhancement of Enoch's elevated profile but also to determine a possible date for the text.

Students of Jewish pseudepigrapha have previously raised concerns about the date of the Slavonic apocalypse, pointing to the fact that the text does not seem to supply definitive evidence for placing it within precise chronological boundaries.

It should be noted that the scholarly attitude towards the Slavonic apocalypse as evidence of Second Temple Jewish developments remains somewhat ambiguous in view of the uncertainty of the text's date. Although students of the apocalypse working closely with the text insist on the early date of the Jewish pseudepigraphon, a broader scholarly community has been somehow reluctant to fully embrace 2 Enoch as a Second Temple Jewish text. ${ }^{17}$ In scholarly debates about

${ }^{14}$ In 2 Enoch 71 , Noah is depicted as a timid relative whose activities are confined to the circle of his family. After Melchisedek's situation was settled, Noah quietly "went away to his own place." Andersen, "2 (Slavonic Apocalypse of) Enoch," 206-7.

151 knoch 89:9.

16 P. Tiller, A Commentary on the Animal Apocalypse of 1 Enoch (Atlanta: Scholars, 1993) 267.

17 The early date of the pseudepigraphon was supported by, among others, the following investigations: R. H. Charles and W. R. Morfill, The Book of the Secrets of Enoch (Oxford: Clarendon 
the Second Temple pseudepigrapha, one can often find references to Francis Andersen's remark that "in every respect 2 Enoch remains an enigma. So long as the date and location remain unknown, no use can be made of it for historical purposes." 18

The uncritical use of this brief statement about 2 Enoch as an enigma "in every respect" unfortunately tends to oversimplify the scholarly situation and diminish the value of the long and complex history of efforts to clarify the provenance and date the text. ${ }^{19}$ The following brief excursus into the history of argurnents against the early date of the text demonstrates the extreme rarity of critical attempts and their very limited power of persuasion.

1. In 1896, in his introduction to the English translation of 2 Enoch, R.H. Charles assigned "with reasonable certainty" the composition of the text to the period between $1-50 \mathrm{CE},{ }^{20}$ before the destruction of the Temple; this view,

Press, 1896); M. I. Sokolov, "Materialy i zametki po starinnoj slavjanskoj litcrature. Vypusk tretij, VII. Slavjanskaja Kniga Enoha Pravednogo. Teksty, latinskij perevod i izsledovanie. Posmertnyj trud avtora prigorovil k izdaniju M. Speranskij", COIDR 4 (1910) 165; G. N. Bonwersch, Das slavische Henochbuch (AGWG.PH Neue Folge Bd.1 Nr.3; Berlin: Weidmannsche Buchhandlung, 1896); N. Schmidt, "The Two Recensions of Slavonic Enoch," JAOS 41 (1921) 307-312; G. Scholem, Ursprung und Anfange der Kabbala (Berlin, 1962) 62-64; M. Philonenko, "La cosmogonie du Livre des secrets d'Hénoch," in: Religions en Egypte: Hellénistique et romaine (Paris: Presses Universitaires de France, 1969) 109-116; S. Pines, "Eschatology and the Concept of Time in the Slavonic Book of Enoch," in: Types of Redemption (eds. R. J. Zwi Werblowsky and C. Jouco Bleeker; SHR, 18; Leiden: Brill, 1970) 72-87; J. C. Greenfield, "Prolegomenon", in: H. Odeberg, 3 Enoch or the Hebrew Book of Enoch (New York: KTAV, 1973) XVIII-XX; U. Fischer, Eschatologie und Jenseitserwartung im hellenistischen Diasporajudentum (BZNW, 44; Berlin: de Gruyter, 1978) 38-41; J. H. Charlesworth, "The SNTS Pseudepigrapha Seminars at "Tübingen and Paris on the Books of Enoch (Seminar Reporr)," NTS 25 (1979) 315-23; J. J. Collins, "The Genre Apocalypse in Hellenistic Judaism," in: Apocalypticism in the Mediterranean World and the Near East (cd. D. Hellholm; Tübingen: Mohr/Sicbeck, 1983) 533; F. Andersen, "2 (Slavonic Apocalypse of) Enoch," in: The Old Testament Pseudepigrapha (ed. J. H. Charlesworth; New York: Doubleday, 1985 [1983]) 1.91-221; M. E. Stone, Jewish Writings of the Second Temple Period: Apocrypha, Pseudepigrapha, Qumran Sectarian Writings, Philo, Josephus (CRINT, 2.2; Assen: Van Gorcum, 1984) 406; A. de Santos Otero, "Libro de los secretos de Henoc (Henoc eslavo)," in: Apocrifos del AT (ed. A. Diez Macho; Madrid: Ediciones Christiandad, 1984) 4.147-202; C. Böttrich, Das slavische Henochbuch (Gütersloh: Gütersloher Verlaghaus, 1995) 812-13. P. Sacchi, Jewish Apocalyptic and its History (JSPSS, 20; Sheffield: Sheffield Academic Press, 1996).

18 Andersen, "2 Enoch," 97.

19 After all it should nor be forgotten that in the same study Francis Andersen explicitly assigns the book to the late first century CE. Andersen, "2 Enoch," 91.

20 In his introduction to the Forbes translation of 2 Enoch in APOT, Charles broadened the range of the dating of the apocalypse, postulating that " 2 Enoch in its present form was written probably between 30 B.C. and $A D 70$. It was wtitten after 30 B.C., for it makes use of Sirach, 1 Enoch, and the Book of Wisdom..., and before A.D. 70; for the temple is still standing." R. H. Charles and N. Forbes, "The Book of the Secret of Enoch," The Apocrypha and Pseudepigrapha of the Old Testament (2 vols.; ed. R. H. Charles; Oxford: Clarendon Press, 1913) 2. 429. This opinion about the early date of 2 Enoch was also supported by Charles' contemporaries, the Russian philologist Matvej Sokolov and German theologian Nathanicl Bonwetsch. Sokolov, Slavjanskaja Kniga Enoha Pravednogo; Bonwetsch, Das slavische Henochbuch; Idem, Die Bücher der Geheimnisse Henochs. 
however, did not remain unchallenged. ${ }^{21}$ In 1918 the British astronomer A. S. D. Maunder launched an attack against the early dating of the pseudepigraphon, arguing that the Slavonic Enoch does not represent an early Jewish text written in the first century CE, but instead is "a specimen of Bogomil propaganda," composed in the Slavonic language in "the 'Middle Bulgarian" period - i.e., between the 12th and 15th centuries. "22 In the attempt to justify her claim, Maunder appealed to the theological content of the book, specifically to its alleged Bogomil features, such as the dualism of good and evil powers. She found that such dualistic ideas werc consistent with the sectarian teaching that "God had two sons, Satanail and Michael." 23 Maunder's study was not limited solely to the analysis of the theological features of the text but also included a summary of the astronomical and calendarical observations which attempted to prove a late date for the text. Her argument against the early dating of the pseudepigraphon was later supported by $\mathrm{J}$. K. Fotheringham, who offered a less radical hypothesis that the date of 2 Enoch must be no earlier than the middle of the seventh century CE. ${ }^{24}$

Scholars have noted that Maunder's argumentation tends to underestimate the thcological and literary complexities of the Slavonic Enoch. 'The remark was made that, after reading Maunder's article, one can be "astonished at the weakness of this argument and at the irrelevant matters adduced in support of it." 25 Charles responded to the criticism of Maunder and Fortheringam in his article published in 1921 in the Journal of Theological Studies, in which he pointed out, among other things, that "the Slavonic Enoch, which ascribes the cntire creation to God and quotes the Law as divine, could not have emanated from the Bogomils." 26

2. Another attempt to question the scholarly consensus about the early date of 2 Enoch was made by Josef Milik in his introduction to the edition of the Qumran fragments of the Enochic books published in 1976.27 In the introductory section devoted to the Slavonic Enoch, Milik proposed that the apocalypse was composed between the ninth and tenth centuries CE by a Byzantine Christian monk who knew the Enochic Pentateuch "in the form with which we are familiar through the Ethiopic version. " 28 In order to support his hypothesis of a late date Milik draws

${ }^{21}$ R. H. Charles and W. R. Morfill, The Book of the Secrets of Enoch (Oxford: Clarendon Press, 1896) xxvi.

22 A. S. D. Maunder, "The Date and Place of Writing of the Slavonic Book of Enoch," The Observatory 41 (1918) 309-16, esp. 316.

23 Maunder, "The Date and Place of Writing of the Slavonic Book of Enoch," 315.

24 J. K. Fotheringham, "The Date and the Place of Writing of the Slavonic Enoch," JIS 20 (1919) 252.

25 A. Rubinstein, "Observations on the Slavonic Book of Enoch," JJS 15 (1962) 1-21, esp. 3.

${ }^{26}$ R. H. Charles, "I the Dare and Place of Writings of the Slavonic Enoch," JTS 22 (1921) 162-3. See also K. Lake, "Ihe Date of the Slavonic Enoch," HTR 16 (1923) 397-398.

27 J. T. Milik, The Books of Enoch: Aramaic Fragments of Qumran Cave 4 (Oxford: Clarendon Press, 1976).

${ }^{28}$ Milik, The Books of Enoch, 109. 
attention to several lexical features of the text. One of them is the Slavonic word 3moypenuemb (zmureniem') ${ }^{29}$ found in 2 Enoch 22:11 which Milik has traced to

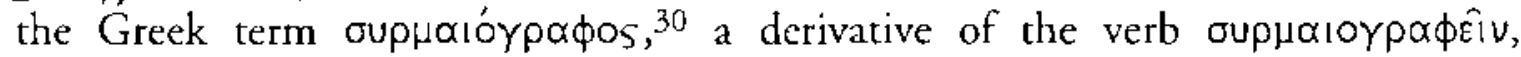
translated as "to write in minuscule, hence quickly." ${ }^{31} \mathrm{He}$ argues that this verb appears to be a neologism which is not attested in any Greek text before the beginning of the ninth century. In addition in his analysis of the lexical features of the apocalypse, Milik directed attention to the angelic names of Arioch and Marioch found in 2 Enoch 33, arguing that they represent the equivalents of the Harut and Marut of the Muslim legends attested in the second sura of the Qur'an.32

John Collins, among others, has offered criticism of Milik's lexical arguments, noting that even if the Slavonic text uses the Greek word oupuaı́oypaфos, "a single word in the translation is not an adequate basis for dating the whole work. " 33 He has also pointed out that "the alleged correspondence of the angels Arioch and Marioch to Harut and Marut of Muslim legend is indecisive since the origin of these figures has not been established." 34

Milik's arguments were not confined only to the lexical features of the apocalypse. He also argued that the priestly succession from Methuselah to Noah's nephew Melchisedek described in the third part of 2 Enoch reflects "the transmission of monastic vocations from uncle to nephew, the very widespread custom in the Greek Church during the Byzantine and medieval periods." 35 This feature in his opinion also points to the late Byzantine date of the pseudepigraphon. Unfortunately Milik was unaware of the polemical nature of the priestly successions detailed in the Slavonic Enoch and did not understand the actual role of $\mathrm{Nir}$ and Melchisedek in the polemical exposition of the story.

It should be noted that Milik's insistence on the Byzantine Christian provenance of the Slavonic apocalypse was partially inspired by the earlier research of the French Slavist André Vaillant who argued for the Christian authorship of the text. ${ }^{36}$ Vaillant's position too generated substantial critical response since the vast

${ }^{29}$ Sokolov, Slavjanskaja Kniga Enoha Pravednogo, 1.23, footnote 13.

${ }^{30}$ Milik's hypothesis is implausible. Most scholars trace the word 3moypenuess (zmureniem') to the Slavonic zmoypona (zmur'na) which corresponds to opúpva, myrrha. J. Kurz, ed., Slounik Jazyka Staroslovenskeho (Lexicon Linguae Palatoslovenicae)(4 vols.; Prague: Akademia, 1966) 1.677-8. Andersen's translation renders the relevant part of 2 Enoch 22:11 as follows: "And Vereveil hurried and brought me the books moteled with myrth." Andersen, "2 Enoch," 141.

31 Milik, The Books of Enoch, 111.

32 Milik, The Books of Enoch, 110.

33 J. J. Collins, "The Genre Apocalypse in Hellenistic Judaism," in: Apocalypticism in the Mediterranean World and the Near East (ed. D. Hellholm; Tübingen: Mohr/Siebeck, 1983) 533, n. 7.

${ }^{34}$ Collins, "The Genre Apocalypse in Hellenistic Judaism," 533, note 7.

35 Milik, The Books of Enoch, 114.

36 A. Vaillant, le Livre des secrets d'Hénoch: Texte slave et traduction franģaise (Textes publiés par l'Institur d'études slaves, 4; Paris: L'Institut d'études slaves, 1976 [1952]). 
majority of readers of 2 Enoch had been arguing for the Jewish provenance of the original core of the text. ${ }^{37}$

The foregoing analysis of the arguments against the early dating of the pseudepigraphon demonstrates how scanty and unsubstantiated they were in the sea of the overwhelming positive consensus. It also shows that none of these hypotheses has been able to stand up to criticism and to form a rationale that would constitute a viable counterpart to the scholarly opinion supporting the early date. Still, one should recognize that, while the adoption of an early date for the text itself does not face great challenges, placing the text within the precise boundaries of Second Temple Judaism is a much more difficult task.

In proceeding to this task one must first understand what features of the text point to the early date of the text in the chronological framework of Second Temple Judaism. It is noteworthy that the vast majority of scholarly efforts have been in this respect directed towards finding possible hints that might somehow indicate that the Temple was still standing when the original text was composed. ${ }^{38}$ Thus, scholars have previously noted that the text does not seem to hint that the catastrophe of the destruction of the Temple has already occurred at the time of its composition. Critical readers of the pseudepigraphon would have some difficulties finding any explicit expression of feelings of sadness or mourning about the loss of the sanctuary.

The affirmations of the value of the animal sacrificial practices and Enoch's halakhic instructions also appear to be fashioned not in the "preservationist," mishnaic-like mode of expression, but rather as if they reflected sacrificial practices that still existed when the author was writing his book. ${ }^{39}$ There is also an intensive and consistent effort on the part of the author to legitimize the central place of worship, which through the reference to the place Akhuzan (a cryptic name for the temple mountain in Jerusalem), is transparently connected in 2 Enoch with the Jerusalem Temple. ${ }^{40}$ Scholars have also previously noted that there are some indications in the text of the ongoing practice of pilgrimage to the central place of worship; these indications could be expected in a text written in the Alexandrian Diaspora. ${ }^{41}$ Thus, in his instructions to the children, Enoch repcatedly encourages

37 Some of the supporters of the idea of the Jewish authorship of the text include the following scholars: Amusin, Andersen, Bonwetsch, Böttrich, Bousset, Charles, Charlesworth, Collins, De Conick, Delcor, Denis, Eissfeldt, Ginzberg, Gieschen, Greenfield, Gruenwald, Fletcher-Louis, Fossum, Harnak, Himmelfarb, Kahana, Kamlah, Mach, Meshcherskij, Odeberg, Pines, Philonenko, Riessler, Sacchi, Segal, Sokolov, de Santos Otero, Schmidt, Scholem, Schürer, Stichel, Stone, and Székeley.

38 U. Fischer, Eschatologie und Jenseitserwartung im hellenistischen Diasporajudentum (BZNW, 44; Berlin: de Gruyter, 1978) 40-41; Böttrich, Das slavische Henochbuch, 812-13.

392 Enoch 59.

40 In Ezek 48:20-21 the Hebrew word "special property of God" is applied to Jerusalem and the Temple. Milik, The Books of Enoch, 114.

${ }^{41}$ Böttrich, Das slavische Henochbuch, 813. 
them to bring the gifts before the face of God for the remission of sins, a practice which appears to recall well-known sacrificial customs widespread in the Second Temple period. ${ }^{42}$ Moreover, the Slavonic apocalypse also contains a direct command to visit the Temple three times a day, advice that would be difficult to fulfill if the sanctuary has already been destroyed. 43

One can see that the crucial arguments for the early dating of the text are all linked to the themes of the Sanctuary and its ongoing practices and customs. These discussions are not new; even Charles employed the references to the Temple practices found in the Slavonic apocalypse as main proofs for his hypothesis of the early date of the apocalypse. Since Charles' pioneering research these arguments have been routinely reiterated by scholars.

Recently, however, Christfried Böttrich attempted to broaden the familiar range of argumentation by bringing to scholarly attention a description of the joyful celebration which in his opinion may fix the date of the apocalypse within the boundaries of the Second Temple period. In his introduction to his German translation of 2 Enoch published in 1995. Böttrich draws attention to a tradition found in Chapter 69 of the Slavonic apocalypse which deals with the joyful festival marking Methuselah's priestly appointment and his animal sacrifices. ${ }^{44}$ According to Böttrich's calculations, this cult-establishing event falls on the 17th of Tammuz, which in his opinion is identified in 2 Enoch as the day of the summer solstice. ${ }^{45}$ Böttrich links this solar event with the imagery found in 2 Enoch 69, where Methuselah's face becomes radiant in front of the altar "like the sun at midday rising up." He then reminds us that, since the second century CE, the 17 th of Tammuz was observed as a day of mourning and fasting because it was regarded as the day when Titus conquered Jerusalem. ${ }^{46}$ Böttrich suggests that the description of the joyful festival in 2 Enoch 69, which does not show any signs of sadness or mourning, indicates that the account and consequently the whole book were written before the fall of Jerusalem and the destruction of the Temple in $70 \mathrm{CE} .47$

Böttrich's observations are of interest, but his understanding of Chapter 69 and especially of the motif of the radiant face of Methuselah, pivotal for his argument, is problematic in the light of the polemical developments detected in the Slavonic apocalypse. Böttrich is unaware of the Noachic polemics witnessed to by the Slavonic apocalypse and does not notice that the description of Methuselah as the

42 Enoch 61:1-5; 2 Enoch 62:1-2.

432 Enoch 51:4: "In the morning of the day and in the middle of the day and in the evening of the day it is good to go to the Iord's temple on account of the glory of your creator." Andersen, "2 Enoch," 178.

44 Bötrich, Das slavische Henochbuch, 813. See also: C. Böttrich, "The Melchizcdek Story of 2 (Slavonic) Enoch: A Reaction to A. Oriov," JSJ 32.4 (2001) 451.

45 thete are many discrepancies and contradictions in the calendarical data presented in the text.

$46 y$. Ta'an. 68c and $b$. Ta'an. $26 b$.

47 Böttrich, Das slavische Henochbuch, 813. 
originator of the animal sacrificial cult in 2 Enoch 69 represents the polemical counterpart to Noah's role, who is portrayed in the Bible and the pseudepigrapha as the pioneer of animal sacrificial practice. ${ }^{48}$ Methuselah, who has never been previously attested in Second Temple materials as the originator of sacrificial cult, thus openly supplants Noah, whose prominent role and elevated status the authors of the Slavonic apocalypse want to diminish. It has already been mentioned that in the course of the Noachic polemics, many exalted features of the hero of the Flood have been transferred to other characters of the book. One of these transferences includes the motif of the luminous face of Noah, the feature which the hero of the Flood acquired at his birth.

As one might recall, the early Enochic materials portray Noah as a wonder child. I Enoch 106, ${ }^{49}$ the Genesis Apocryphon,, 50 and possibly 1Q1951 depict him with a glorious face and eyes "like the rays of the sun." I Enoch 106:2 relates that when the new-born Noah opened his eyes, the whole house lit up. The child then opened his mouth and blessed the Lord of heaven. Scholars have previously noted ${ }^{52}$ that the scene of the glorious visage of the young hero of the Flood delivering blessings upon his rising up from the hands of the midwife has a sacerdotal significance and parallels the glorious appearance and actions of the high priest. ${ }^{53}$ It manifests the portentous beginning of the priestly-Noah tradition. ${ }^{54}$ The priestly features of Noah's natal account are important for discerning the proper meaning

${ }^{48}$ M. Stone, "l'he Axis of History at Qumran," Pseudepigraphic Perspectives: The Apocrypha and the Psestepigrapha in Light of the Dead Sea Scrolls (cds. E. Chazon and M. E. Stone; STDJ 31; Leiden: Brill, 1999) 138.

49 I Enoch 106:5". .. his eyes (are) like the rays of the sun, and his face glorious..." M. Knibb, The Ethiopic Book of Enoch: A New Edition in the Light of the Aramaic Dead Sea Fragments (2 vols; Oxford: Clarendon Press, 1978) 2.244-5.

${ }^{50} \mathrm{lQapGen} 5: 12-13$ ". .his face has been lifted to me and his eyes shine like [the] $s[\mathrm{un} . .$.$] (of)$ this boy is flame and he..." F. García Marcínez and E. J. C. 'ligchelaar (eds.), The Dead Sea Scrolls Study Edition (2 vols.; Leiden; New York; Köln: Brill, 1997) 1.31.

51 A similar tradition is reflected in 1Q19. 1Q19 3: ". ..were aston[ished ...] [... (not like the children of men) the fir]st-born is born, but the glorious ones [...] [...] his father, and when Lamech saw $[\ldots][\ldots]$ the chambers of the house like the beams of the sun [...] to frighten the [...]." $1 Q 19$ 13:" "[...] because the glory of your face [...] for the glory of God in [...] $[\ldots$ he will] be exalted in the splendor of the glory and the beauty [...] he will be honorcd in the midst of [...]. "García Martínez and Tigchelaar (eds.). The Dead Sea Scrolls Study Edition, 1.27.

52 C. H. T. Fletcher-Louis, All the Glory of Adam: Liturgical Anthropology in the Dead Sea Scrolls (STDJ, 42; Leiden: Brill, 2002) 33ff.

53 Crispin Fletcher-Louis notes parallels between this scene and the description of the ideal high priest from Sirach 50. He argues that "in Sirach 50 the liturgical procession through Simon's various ministrations climaxes with Aaron's blessings of the people (50:20, cf. Numbers 6) and a call for all the readers of Sirach's work 'ro bless the God of all who everywhere works greater wonders, who fosters our growth from birth and deals with us according to his mercy' $(50: 22)$. So, too, in ! Enoch 106:3 the infant Noah rises from the hands of the midwife and, already able to speak as an adult, 'he opened his mouth and blessed the Lord." Fletcher-Louis, All the Glory of Adam, 47.

54 Fletcher-Louis argues that "the staging for [Noah's] birth and the behavior of the child have strongly priestly resonances." Fletcher-Louis, All the Glory of Adam, 46. 
of the symbolism of Methuselah's luminous visage in 2 Enoch 69.

In his analysis of the account, Böttrich recognizes that the description of Methusclah's radiant face alludes to the picture of the high priest Simon attested in Sirach 50:1-24. Still, Böttrich is unable to discern the Noachic meaning of this allusion. Meanwhile Fletcher-Louis clearly sees this Noachic link, demonstrating that Methuselah's radiant face in 2 Enoch 69 is linked not only to Sirach 50:5-11 but also to 1 Enoch 106:255 and 1Q19.56 Sirach's description of the high priest Simon serves here as an intermediate link that elucidates the connection between Noah and Methuselah. All three characters are shating the identical priestly imagery. Fletcher-Louis notes strong parallelism between Simon's description and the priestly features of the story of Noah. He observes that

this description of Simon the high priest comes at the climax of a lengthy hymn in praise of Israel's heroes which had begun some six chapters earlier with (Enoch and) Noah (44:16-17), characters whose identity and purpose in salvation-history the high priest gathers up in his cultic office. Obviously, at the literal level Noah's birth in 1 Enoch 106:2 takes place in the private house of his parents. However, I suggest the reader is meant to hear a deeper symbolic reference in that house to the house (cf. Sirach 50:1), the Temple, which Simon the high priest illuminates and glorifies. Just as Simon appears from behind the veil which marks the transition from heaven to earth and brings a numinous radiance to the realm of creation at worship, so Noah breaks forth from his morher's waters to illuminate the house of his birth. ${ }^{57}$

It has been mentioned that Böttrich points to the possible connection of the radiance of Methusclah's face to solar symbolism. Nevertheless, he fails to discern the proper meaning of such a connection, unable to recognize the Noachic background of the imagery. It is not coincidental that in the Noachic accounts the facial features of the hero of the Flood are linked to solar imagery. Fletcher-Louis notes the prominence of the solar symbolism in the description of Noah's countenance; his cyes are compared with "the rays of the sun." He suggests that "the solar imagery might ultimately derive from the Mesopotamian primeval history where the antediluvian hero is closely identified with the sun. "58 Yet, in the Second Temple period such solar imagery has taken on distinctivcly priestly associations. ${ }^{59}$

In the light of the aforementioned traditions, it is clear that Methuselah, who in 2 Enoch 69 inherits Noah's priestly office is also assuming there the features of his

55 Fletcher-Louis, All the Glory of Adam, 50.

56 He notcs that che statement "I shall glorify you in front of the face of all the peoplc, and you will be glorified all the days of your life" (2 Enoch 69:5) and the references to God "raising up" a priest for himself in 69:2,4 "is intriguingly reminiscent of 1Q19 13 lines 2-3." Fletcher-Louis, All the Glory of Adam. 50.

57 Fletcher-Louis, All the Glory of Adam, 47.

58 Fictcher-Louis, All the Glory of Adam, 46.

${ }^{59}$ Fletcher-Louis, All the Glory of Adam, 46. 
appearance as a high priest, one of which is the radiant visage associated with solar symbolism. The radiant face of Methuselah in 2 Enoch 69 thus represents a significant element of the polemics against the priestly Noachic tradition and its main character, whose facial features were often compared to the radiance of the sun.

\section{Noachic Polemics and the Date of the Text}

The analysis of the Noachic background of the priestly and sacrificial practices in 2 Enoch leads us to the important question about the role of Noachic polemical developments in discerning the early date of the apocalypse. It is possible that the Noachic priestly polemics reflected in 2 Enoch represent the most important and reliable testimony that the text was composed when the Second Temple was still standing.

The central evidence here is the priestly features of the miraculous birth of the hero. It has been already demonstrated that the main concern of the story of the wondrous birth was sacerdotal; the story is permeated with imagery portraying the newborn as the high priest par exellence. It also has been shown that the antiNoachic priestly tradition reflected in 2 Enoch is not separate from the EnochicNoachic axis but belongs to the same set of conceptual developments reflected in such Second Temple Enochic and Noachic materials as 1 Enoch 106, the Genesis Apocryphon, and 1Q19.60 The traditions prevalent in these accounts were reworked by the Enochic author(s) of the Slavonic apocalypse in response to the new challenging circumstances of the mediatorial polemics. 'The priestly features of 2 Enoch's account of the wondrous birth might thus point to the fact that this narrative and, as a consequence, the whole macroform to which it belongs was written in the Second 'Temple period. It should be emphasized again that the distinct chronological marker here is not the story of the wonder child itself, which was often imitated in later Jewish materials, but the priestly features of the story that are missing in these later improvisations.

The analysis of the later pseudepigraphic and rabbinic imitations of the account of Noah's birth shows that the priestly dimension of the story never transcended the boundaries of the Enochic-Noachic lore, nor did it cross the chronological boundary of $70 \mathrm{CE}$ since it remained relevant only within the sacerdotal context of the Second Temple Enochic-Noachic materials. Although some later Jewish authors were familiar with the account of Noah's birth, this story never again became the subject of priestly polemics once the dust of the destroyed Temple settled.

Several examples can illustrate this situation. In search of the later variants of the story of the wonder child Fletcher-Louis draws attention to the account of

60 Fletcher-Louis suggests that the authors of Jubilees probably also kncw the story of Noah's birth, since the text mentions his mother Bitenosh. Fletcher-Louis, All the Glory of Adam, 35, n. 9. 
Cain's birth in the primary Adam books. ${ }^{61}$ Thus, the Latin Life of Adam and Eve 21:3 relates that Eve "brought forth a son who shone brilliantly (lucidus). At once the infant stood up and ran out and brought some grass with his own hands and gave it to his mother. His name was called Cain." ${ }_{2}$ Fletcher-Louis points out that this narrative of the wonder child recalls the story of Noah. Yet he notes that "all the features which in the birth of Noah signal the child's priestly identity-solar imagery, birth in a house and child's blessing of God are markedly absent in the Adamic story. "63 Such absence of the significant features can be an indication that the final form of the text was composed outside the chronological boundaries of Second Temple Judaism and therefore, unlike 2 Enoch, displays no interest in the sacerdotal dimension of the story. Although the authors of the Latin $L A E$ might have been familiar with the narrative of Noah's birth, the priestly concerns associated with the story were no longer relevant for them.

The same situation of the absence of the sacerdotal concern is observable also in the rabbinic stories of Moses' birth reflected in b. Sotah 12a, ${ }^{64}$ Exod. R. 1:20, ${ }^{65}$ Deut. R. 11:10,66 PRE 48,67 and the Zohar II.11b, ${ }^{68}$ whose authors were possibly cognizant of the Noachic natal account.

${ }^{61}$ Fletcher-Louis, All the Glory of Adam, 51-52.

62 G. A. Anderson and M. E. Stone, A Synopsis of the Books of Adam and Eve. Second Revised Edition (SBLEJL, 17; Atlanta: Scholars, 1999), 24-24E. See also Armenian and Georgian versions of IAE: "I'hen, when she bore the child, the color of his body was like the color of stars. At the hour when the child fell into the hands of the midwife, he leaped up and, with his hands, plucked up the grass of the carth..." (Armenian). "Eve arose as the angel had instructed her: she gave birth to an infant and his color was like that of the stars. He fell into the hands of the midwife and (at once) he began to pluck up the grass..." (Gcorgian). A Synopsis of the Books of Adam and Eve, 24E.

63 Fletcher-Louis, All the Glory of Adam, 52.

64 "He was born circumcised; and the Sages declare, At the time when Moses was born, the whole house was filled with light - as it is written here, 'And she saw him that he was good' (Ex 2:2), and elsewhere it is written, 'And God saw the light that it was good' (Gen 1:4)." Sotah 12a.

65 ". ..she saw that the Shechinah was with him; that is, the 'it' refers to the Shechinah which was with the child." Midrash Rabbah (trs. H. Freedman and M. Simon; 10 vols.; I.ondon: Soncino, 1961) 3.29-30.

66 "Moses replied: 'I am the son of Amram, and came out from my mother's womb without prepuce, and had no necd to be circumcised; and on the very day on which I was born I found myself able to speak and was able ro walk and to converse with my father and mother ... when I was three months old I prophesied and declared that I was destined to receive the law from the midst of flames of fite." Midrash Rabbah, 7.185.

67 "Rabbi Nathaniel said: the parents of Moses saw the child, for his form was like that of an angel of God. "They circumcised him on the eight day and they called his name Jekuthiel." Pirke de Rabbi Fliezer (tr. G. Friedlander; 2nd cd.; New York: Hermon Press, 1965) 378.

68 "She saw the lighe of the Shekinah playing around him: for when he was born chis light filled the whole house, the word 'good' here having the same reference as in the verse 'and God saw the light that it was good' (Gen 1:4)." The Zahar (trs. H. Sperling and M. Simon; 5 vols.; London and New York: Soncino, 1933) 3.35. Sec also Samaritan Molad Mosheh: "She became pregnant with Moses and was great with child, and the light was present." Samaritan Documents Relating to Their History, Religion and Life (tr. J. Bowman; Pittsburgh: Pickwick, 1977) 287. 
Reflecting on this evidence Fletcher-Louis notices that, although the authors of the rabbinic accounts of Moses' birth appear to be familiar with Noah's narrative, these materials do not show any interest in the sacerdotal dimension of the original story. Buried in the ashes of the destroyed Sanctuary, the alternative portrayal of the Noachic priestly tradition was ncither offensive nor challenging for the heirs of the Pharisaic tradition. Fletcher-Louis observes that, although Moses, like Noah, is able to speak from his birth and the house of his birth becomes flooded with light, "the differences of the specifically priestly form of that older tradition can be clearly seen." 69 He points out that while Moses is able to speak as soon as he is born, he does not bless God, as do Noah and Melchisedek. ${ }^{70}$ The same paradigm shift is detected in the light symbolism. While in the rabbinic stories the whole house becomes flooded with light, the Mosaic birth texts do not specifically say that Moses is himself the source of light. ${ }^{71}$ These differences indicate that, unlike in 2 Enoch, where the priestly concerns of the editors come to the fore, in the rabbinic accounts they have completely evaporated. ${ }^{72}$ Fletcher-Louis notices that "the fact that in the Mosaic stories the child is circumcised at birth indicates his role as an idealized representative of every Israelite: where Noah bears the marks of the priesthood, Moses carries the principal identity marker of every member of Israel, irrespective of any distinction between laity and priesthood."73

The marked absence of sacerdotal concerns in the later imitations of the story may explain why, although the rabbinic authors knew of the priestly affiliations of the hero of the Flood, the story of his priestly birth never appeared in the debates about the priestly successions. This fact convincingly demonstrates that the Noachic priestly tradition reflected in 2 Enoch can be firmly placed inside the chronological boundaries of the Second Temple period, which allows us to safely assume a date of the Melchisedek story and the entire apocalypse before $70 \mathrm{CE}$.

\section{Summary}

L'articolo indaga la sistematica polemica contro la tradizione sacerdotale noachica, che troviamo nell Enoc Slavo. L'analisi dimostra che la polemica rappresenta la risposta della tradizione enochica alle sfide lanciate al profilo classico del settimo eroe antidiluviano dalle tradizioni del tardo Secondo Tempio. Lo studio afferma che le tradizioni ostili a Noè che troviamo in $2 \mathrm{Enoc}$ offrono la prova decisiva in favore di una datazione alta di questo testo, non più tardi del 70 e.v., in quanto riflettono una par-

${ }^{69}$ Fletcher-Louis, All the Glory of Adam, 52.

${ }^{70}$ Fletcher-Louis, All the Glory of Adam, 52.

71 Fletcher-Louis reminds that "the illumination of the house through Noah's eyes and the comparison of the light to that of the sun are specifically priestly features of Noah's birth." FletcherLouis, All the Glory of Adam, 52-53.

72 Although the priestly affiliation of the hero of the Flood was well known to the rabbinic authors, as the story of Shem-Melchisedek has already demonstrated.

${ }^{73}$ Fletcher-Louis, All the Glory of Adam, 53. 
ticolare situazione del sacerdozio, tipica di un periodo in cui il Tempio era ancora in funzione. L'articolo dimostra che la polemica antinoachica in 2Enoc appartiene alla medesima corrente di antiche testimonianze enochiche di una tradizione sacerdotale collegata a Noè che ritroviamo anche nell'Apocrifo della Genesi e nella Epistola di Enoc, opere queste scritte prima della distrizione del secondo Tempio. 